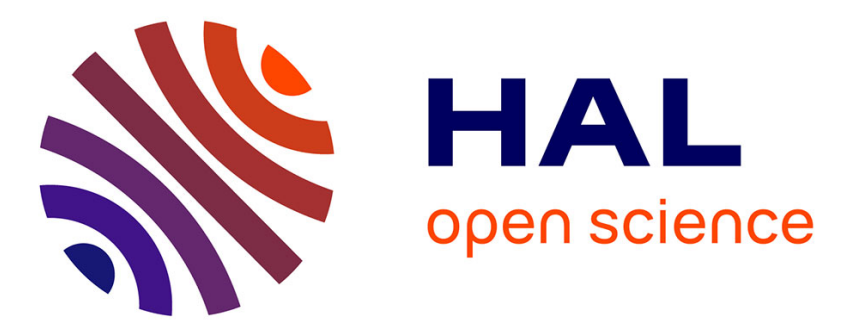

\title{
Lessons for Today from an Early Outreach Effort in Oceanography: The 1884 Exposition of the Travailleur and the Talisman as Presented by the Press
}

John Dolan

\section{- To cite this version: \\ John Dolan. Lessons for Today from an Early Outreach Effort in Oceanography: The 1884 Exposition of the Travailleur and the Talisman as Presented by the Press. Limnology and Oceanography Bulletin, 2020, 10.1002/lob.10401 . hal-02958824}

\section{HAL Id: hal-02958824 \\ https: / hal.sorbonne-universite.fr/hal-02958824}

Submitted on 6 Oct 2020

HAL is a multi-disciplinary open access archive for the deposit and dissemination of scientific research documents, whether they are published or not. The documents may come from teaching and research institutions in France or abroad, or from public or private research centers.
L'archive ouverte pluridisciplinaire HAL, est destinée au dépôt et à la diffusion de documents scientifiques de niveau recherche, publiés ou non, émanant des établissements d'enseignement et de recherche français ou étrangers, des laboratoires publics ou privés. 
https://doi.org/10.1002/1ob.10401

Sous Presse: Limnology and Oceanography Bulletin

\title{
Lessons for Today From an Early Outreach Effort in Oceanography: The 1884 Exposition of the Travailleur and the Talisman as presented by the press
}

John R. Dolan

Laboratoire d'Océanographie de Villefranche-sur-Mer

Sorbonne Université CNRS UMR 7093

Station Zoologique, 06230 Villefranche-sur-Mer, France

dolan@obs-vlfr.fr

\begin{abstract}
The campaigns of the Travailleur and the Talisman (1880-1883) were the first French expeditions to explore the deep-sea. In early 1884, the campaign participants mounted a temporary exhibition in the Paris Natural History Museum displaying specimens collected and the equipment used. The exhibition included not only fantastic creatures but also 'hands-on' items, such as water samplers and sounders that could be touched, and microscopes to examine sediment samples. It was an enormous success with the public. The success was probably partly due to the fact the main organizer, Alphonse Milne Edwards, was somewhat of a media figure of the time. Complaints that the exhibition space was too small for all the objects exhibited and the crowds attracted were explained by a claim that it was conceived to show expedition results to funding agencies and the scientific community; the crowds were unexpected. However, a review of the press coverage suggests that the organizers used the media very skillfully to promote it. Here the Exposition of the Travailleur and Talisman is presented as described through the press coverage to underline lessons for outreach today from this effort 136 years ago.
\end{abstract}

\section{Announcing the Exposition: 'build buzz!'}

In the morning of August 31st, 1883, the Talisman, after 3 months of sampling the depths of the North Atlantic, returned to her home port of Rochefort on the Atlantic coast of France. According to press reports, the scientists had run out of jars and alcohol to store and preserve specimens dredged from the deep. The cruise of the Talisman was the fourth and last of a series of deep-sea explorations organized by Henri Folin, the Harbor Master of Biarritz, and Alphonse Milne Edwards, a Professor of the Paris Museum of Natural History and one of the youngest members of the Academy of Sciences. The three previous cruises in 1882, 1881, and 1880 had been with the side-wheel steamer, the Travailleur (for more on the expeditions see Dolan 2020). On December 17th, 1883, Milne Edwards presented a preliminary report to the Academy of Sciences on the North Atlantic sampling. He concluded with the announcement that an exposition of the results of the deep-sea explorations of both the Travailleur and the Talisman would open soon at the Paris Museum of Natural History (Milne Edwards 1883). 
The expeditions had been followed in the press; Milne Edwards was a wellknown personality. For example, in Jules Verne's 1871 book "20,000 Leagues Under The Sea", the narrator of the story, "Monsieur Aronnax, professeur au Muséum de Paris", describes Milne Edwards as his illustrious master (Verne 1871, pg. 142). Thus, it is perhaps not surprising that his presentation to the Academy and the news concerning an upcoming exposition was reported widely in the press; within a week 10 newspapers had carried short, two paragraph notices or long articles (Fig. 1), some on the first page. Many used the same words that first appeared in the Figaro on December 18, suggesting that newspaper made free use of each other's texts or a press release had been circulated. No dates or any details were given concerning the exposition, even in a long article by George Pouchet (1883) in late December, and he was the head of comparative anatomy at the Museum and so likely privy to the exposition organization and schedule.

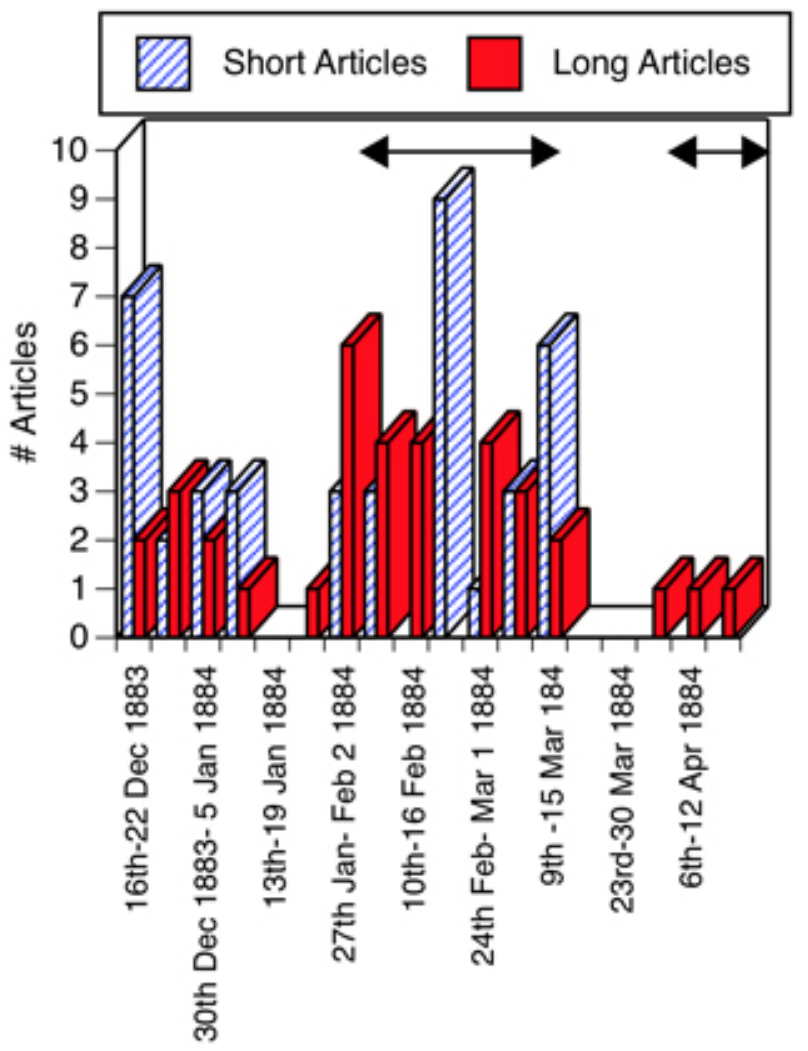

FIG 1. Press coverage of the exposition from the third week of December 1883 when Milne Edwards announced it would be held 'soon' to the third week of April 1884, the definitive end of the exposition. Short Articles are 1-2 paragraphs notices; Long Articles are 3 paragraphs to multi-page pieces. The arrows indicate the periods in which the exposition was open to the public. Press coverage references are provided in the supplementary file.

Although many articles later appeared in the press, the first article giving details of the displays did not appear until January 23, just a week before the exhibit opened. Milne Edwards invited a journalist from the Figaro for a sneak preview (Giffard 1884). However, again exposition dates, hours and location were not mentioned. A few days later (January 28th), another long article appeared in another newspaper, La France, describing in some detail the 
wonders to be seen soon and thanking Milne Edwards for his kind invitation to visit the not quite fully installed exposition (Second 1884). The precise location was given but without any other practical details. Purposefully or not, the missing vital details on the exposition resembled a "watch this space" or "stay tuned" publicity campaign.

\section{The Unveiling of the Exposition: 'use endorsements and give practical details'}

The exposition opening was not announced in advance. On the opening day, January 31,1884 , announcements appeared noting the inauguration of the exposition at 1:00 that afternoon. Among the personalities in attendance were the Minister of Education, Naval Officers, including admirals and the captains of both the Travailleur and Talisman, all the professors of the Natural History Museum and various politicians, including senators. The announcements gave the exact address of the exposition. All the notices mentioned that admission was free and most noted that the passes were given out at the main administration building of the Natural History Museum. The inclusion of the exact address and directions for obtaining free passes was important to mention because the exposition was not within the grounds of the Museum. Oddly enough, there were no mentions of opening hours. Only one article mentioned a possible closing date, saying that the exposition would run through the entire month of February.

\section{Descriptions of the Exposition: 'don't miss it!'}

During the period when the exposition was open, press coverage was maximal and a large number of long articles appeared (Fig. 1). Fairly detailed descriptions of what was on display in the exposition appeared. Museum staff were involved in reaching out to the press. For example, an article acknowledged an invitation to visit the exposition by M. Sauvage, the head of the Herpetology Museum of the Natural History Museum (Bert 1884). Some articles were quite prominent, 'page 1 , above the fold'. Most focused on the biological specimens but some did draw attention to the instruments and custom-made steel cable used in the expedition. The deep-sea fish and sponges were most frequently highlighted. Mention was made that microscopic creatures could be seen in the exposition as microscopes were available for visitors to see the shells of foraminifera and radiolarians in sediment samples. One article was whimsically signed "Captain Nemo" making specific reference to Jules Verne's '20,000 Leagues Under the Sea' (Nemo 1884). One article included the complaint that the exposition area was too small making it difficult to appreciate all that was on display. Mentions finally appeared of the opening hours (12:00-4:00) along with the number of visitors on a Sunday afternoon (400).

\section{Due to popular demand the Exposition is extended: 'limited time offer!'}

On February 21 about a month after the opening, a short notice appeared in $L a$ Gazette National, stating that due to the popularity of the exposition it would be extended until March 15. The notice, usually using the exact same text, appeared in 10 other newspaper between the 22nd and 24th of February. Again, the appearance of the same text in multiple titles suggests either copying from one another or use of a notice from the Museum. Regardless, it should be recalled that a closing date had previously been mentioned only once in all 35 of the 
previous published notices and articles. The notice then served to inform all that the exposition was very popular and would end soon.

\section{A picture is worth a thousand words: 'join the crowd, see the show before it's too late!'}

Newspapers at the time were usually four pages of text without any illustrations. Magazines, weeklies and monthlies, however often featured illustrations. The first illustration of the exposition in the press (of those I found) appeared on February 23, just a few days after the notices of the exposition extension. It was in an article by Henri Filhol (1884), a participant in the campaigns of the Travailleur and the Talisman, and a Professor at the Museum of Natural History. The article in the magazine La Nature was one a series of short articles on the Talisman cruise by Filhol, many of which were translated into English and published in Science along with illustrations (Anon. 1884a). The exposition illustration (Fig. 2) showed a well-dressed public examining jars of specimens. Among the visitors, women and children were prominent suggesting that the exposition was of interest to a broad audience.

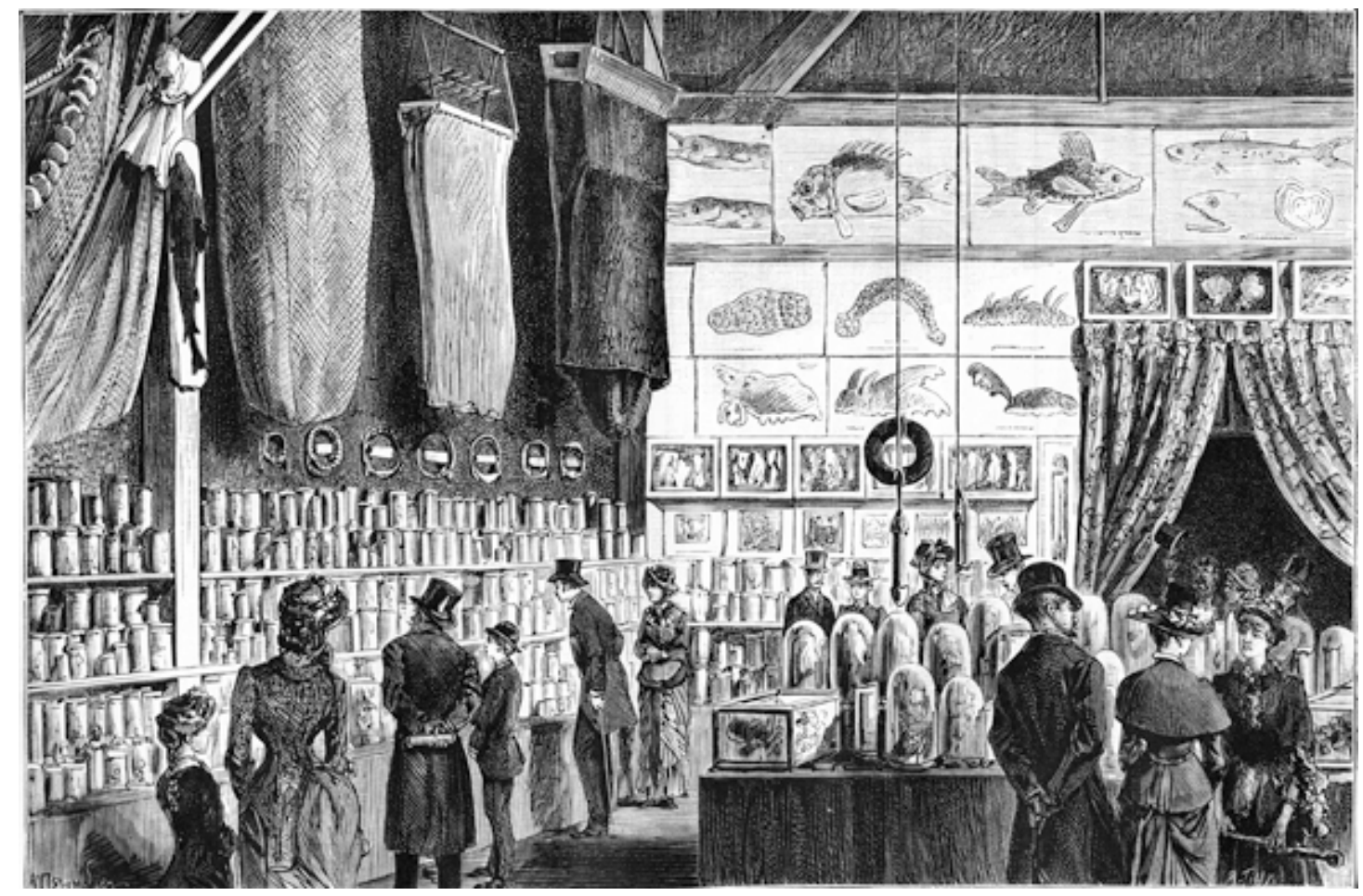

FIG 2. The illustration from Filhol in La Nature published on February 23, 1884 was the first illustration of the exposition to appear in the press. Note the conspicuous presence of women and children. Filhol was one of the expedition participants and a professor at the Natural History Museum.

The next day in the appropriately titled Journal Illustré an unauthored article on the exposition appeared which included a large format illustration $(22 \times 34 \mathrm{~cm})$. The presentation of the exposition was quite different from that of Filhol's. The exposition was shown as being in a spacious very high-ceiling space within a grandiose frame decorated with odd creatures and the ships (Fig. 3). Again, women were prominent among the exposition viewers but no children were 
shown. The exposition was shown as a spectacle as though the viewer is looking at an opera on stage.

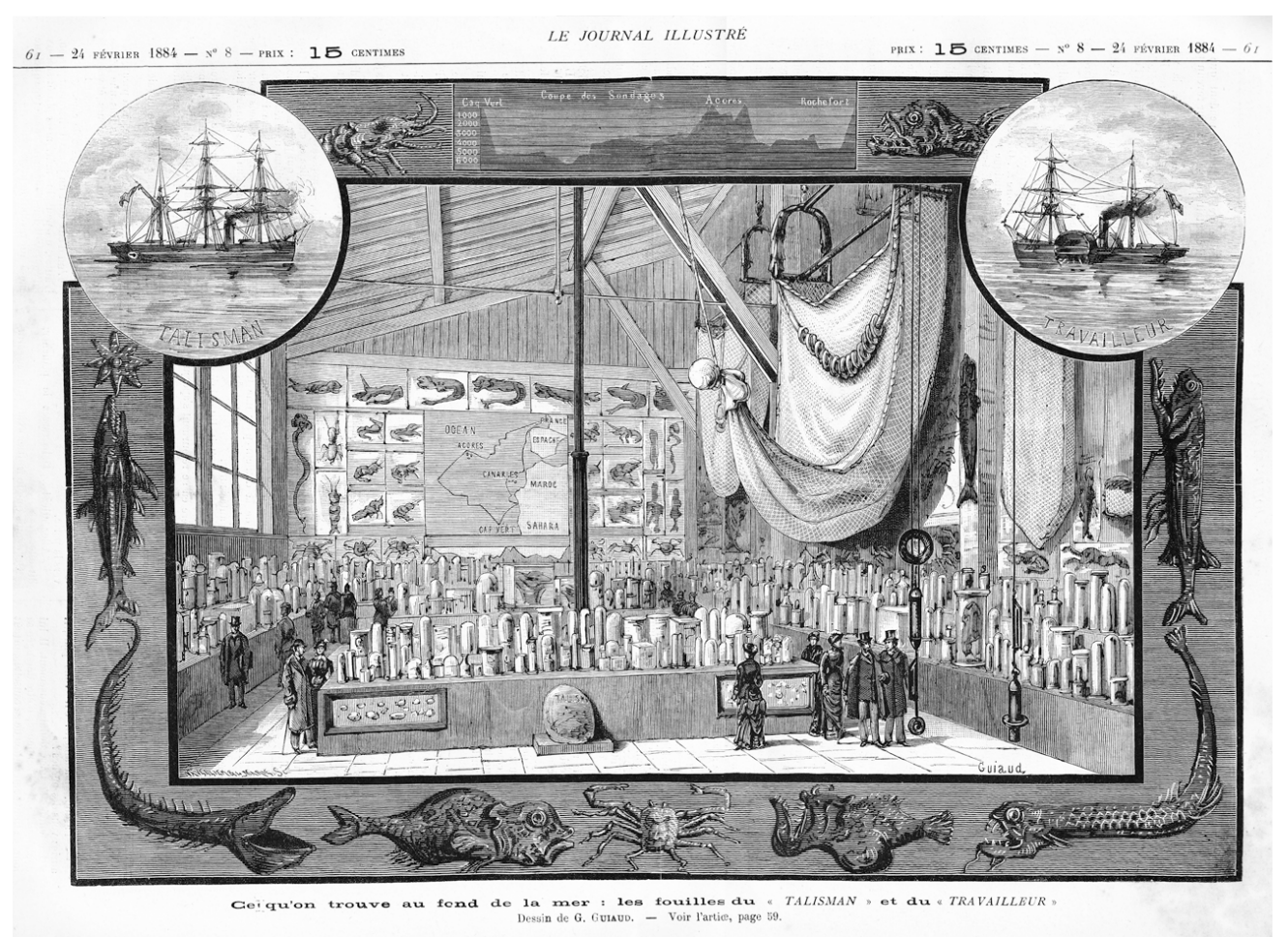

FIG 3. The large format illustration $(22 \times 32 \mathrm{~cm})$ in the 24 February issue of Le Journal Illustré. Note the grandiose presentation.

On March 8th, just a week before the scheduled end of the exposition, appeared another article with an illustration of the exposition. It was authored by yet another of the campaign participants and also professor at the Natural History Museum, Edmond Perrier. In the article in Science et Nature, Perrier admitted that the space was too small and explained that the crowds attracted to exposition were unexpected as it was thought to interest only scientists and those wanting to see the result of public spending (Perrier 1884). Given the efforts exerted by museum staff (Pouchet, Milne Edwards, Sauvage, Filhol, and Perrier himself) to promote the exposition in the press, his statement appears disingenuous.

The illustration in Perrier's article on the exposition (Fig. 4) was drawn by Armand-Lucien Clément. He was a scientific illustrator and entomologist whose illustrations were frequently used in publications by the staff of the Museum of Natural History. He also did murals for the Museum. The illustration by Clément is likely then to be a faithful representation. Among the visitors examining biological specimens, prominently shown are a man looking up at one of the dredges suspended on the wall, and another handling a water sampler suspended on a cable. Thus, the public were shown to be interested not only in the odd creatures, but also the equipment used in the deep-sea explorations. 


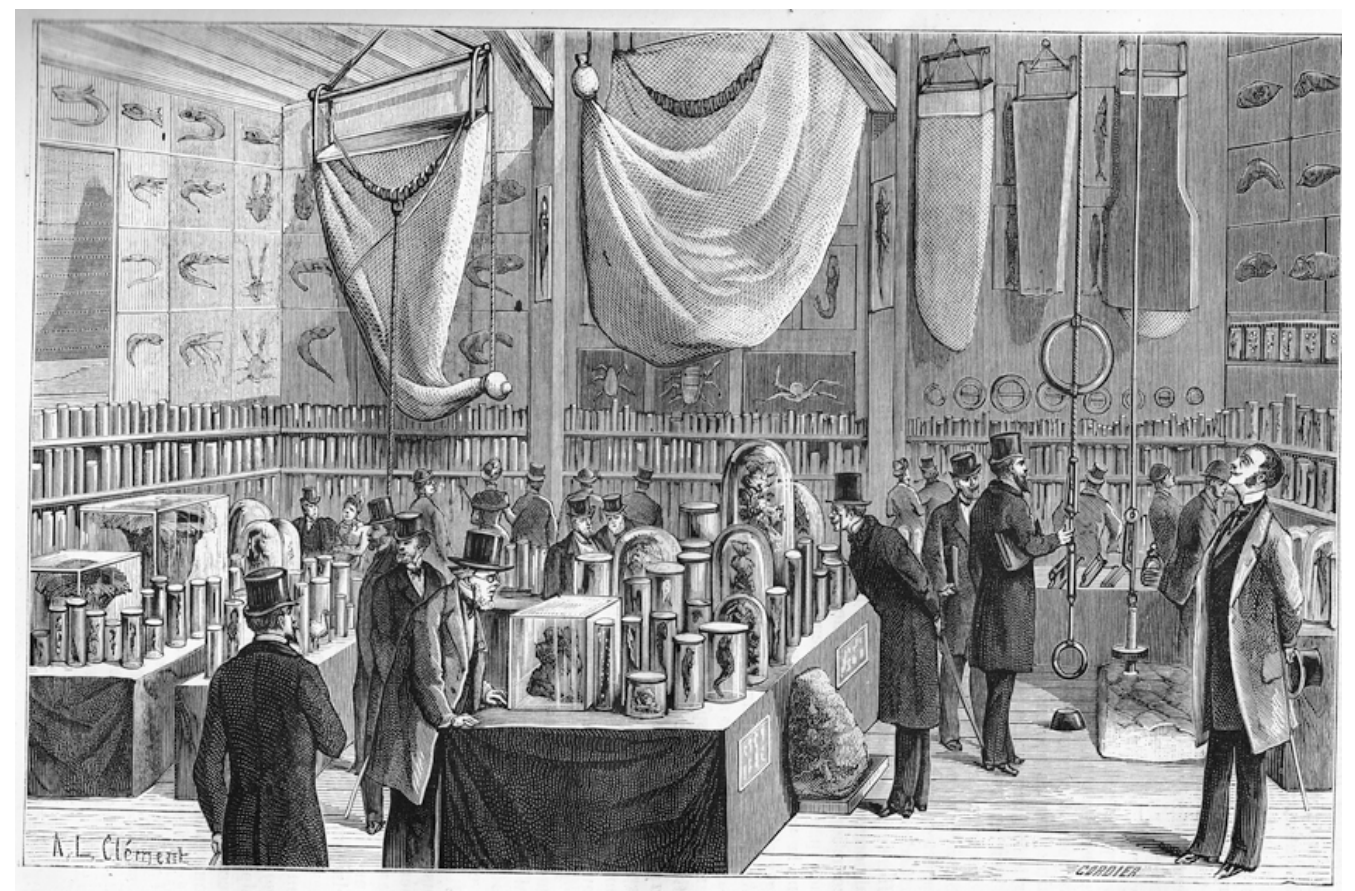

FIG. 1. - L'exposition du Talisma

FIG 4. From an article published on March 8, 1884 by Edmund Perrier in Science et Nature. Perrier was one of the expedition participants. In the illustration, note at the right, the man touching the water sampler, and another admiring the dredge. The illustrator shows oceanographic sampling equipment and deep-sea organisms interesting to the public. This view of the exposition by Armand-Lucien Clément, an illustrator and entomologist often employed by Muséum scientists, is probably the most accurate depiction of the exposition.

The last illustration (of those I found) was in another 'illustrated journal', Le Univers Illustré. It was a very large illustration $(29 \times 49 \mathrm{~cm})$, filling two pages (Fig. 5). In the illustration, the exposition scene is surrounded by vignettes showing deep-sea creatures, the ships, the crew, depth charts, etc. Notable in the depiction of the visitors are the differences between the two men shown in the foreground. The man at the left is dressed as are most of the men shown in all the other illustrations, wearing a top hat and sporting a full beard. The figure at the right is dressed quite differently, wearing a cap, a uniform-like coat, and sporting a waxed moustache. The two men of likely distinct social classes are among the visitors to the exposition. 


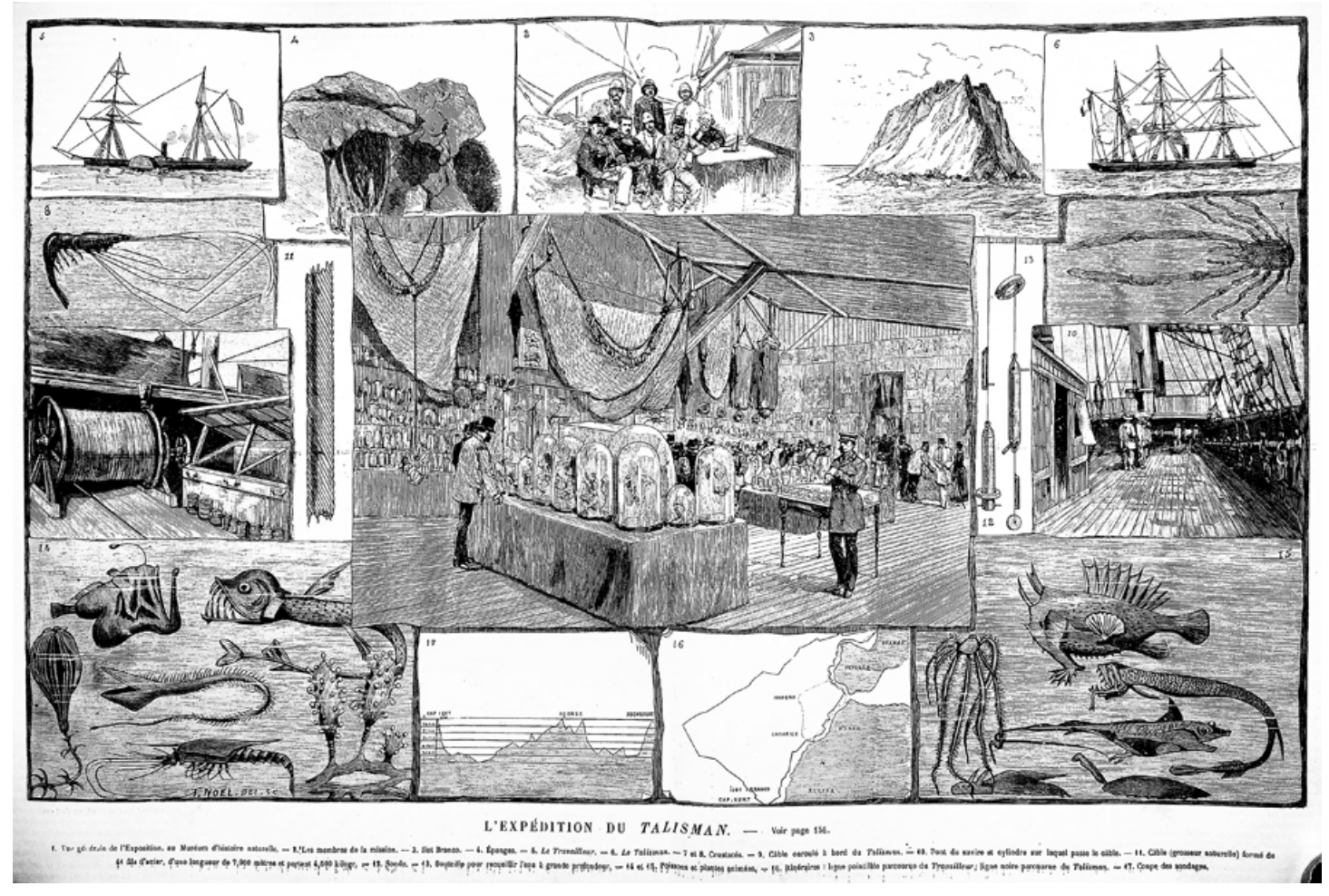

FIG 5. From an article published on March 8, 1884 on the exposition in L'Univers Illustré. Note that the two men shown in foreground are dressed quite differently, suggesting that different social classes viewed the exhibit.

\section{Reminders: 'Still Popular! Don't be Left Out!'}

On March 7th a text announcing that the exposition 'continues to draw large crowds' was published in three newspapers using the exact same text. Oddly enough the text did not mention that the exposition was to end soon.

\section{The Exposition Re-opens: 'Encore performance, in case you missed it!'} Closed on March 15 1884, the exposition was re-opened for 2 weeks, from the 7 th to the 20th of April, to coincide with a large joint meeting of French scientific societies. Coverage of the re-opening was different compared to the preceding periods. First, the re-opening was announced in advance, in six newspapers between March 12 and March 15. While the same text was used, the announcements were spread out across four days. On March 15th in an article in a magazine aimed at adolescents, a long description of the exposition was published with the remark that the exposition might be closing. Another long article, over $1 / 2$ page, described in enthusiastic detail the wonders to be seen and urging readers that had not seen the exposition to take advantage of the short re-opening. Other than the mid-March announcement of the exposition reopening, there were no obvious efforts of museum staff to promote the exposition during the April days of the exposition. One might speculate that they were occupied with meetings occurring at the same time. 


\section{The Legacy of the Exposition}

The exposition may have been of more lasting importance than the scientific findings of expeditions. To begin with, it likely inspired other expositions. The example was soon replicated for the Cap Horn Expedition held in the 'Palais de l'Industrie'. The Cap Horn Expedition was a major undertaking, involving surveys of the region and occupation of a base cap for over a year. The Romanche, the expedition vessel, returned to France in late November 1883, a few months after the Talisman cruise ended. Just a few days after the closing of the Travailleur and Talisman Exposition, the Cap Horn Exposition opened with a minister and other notables in attendance. The exposition featured a wide variety of items from instruments to measure terrestrial magnetism to a whale skeleton, stuffed seals, 'native' boats and huts (Anon. 1884b). Open for a 2 full months, it was given attention in the press but considerably less than what the Travailleur and Talisman exposition received. A total of 25 articles appeared mentioning the exposition only 5 long articles among them. The Travailleur and Talisman exposition was the subject of 40 short articles and 35 long articles. In the articles on the Cap Horn Exposition, there were no signs of the expedition participants having been involved actively in promoting the exposition perhaps partly explaining the lighter press coverage it received.

The scientific results of the expeditions of the Travailleur and the Talisman, while not negligible, have been characterized as perhaps less important than the interest they generated in exploring the deep-sea (Estival 2003). Images of the Talisman probing the deep-sea were still appearing in the press over a year after the exposition closed (Fig. 6). The exposition is said to have directly inspired the founding of the Oceanographic Museum of Monaco by Prince Albert (CarpineLancre, 2001). It is then well worth keeping in mind the possibility that outreach efforts, if they inspire others, can have a considerable long-term impact, well beyond the subject of the outreach. 


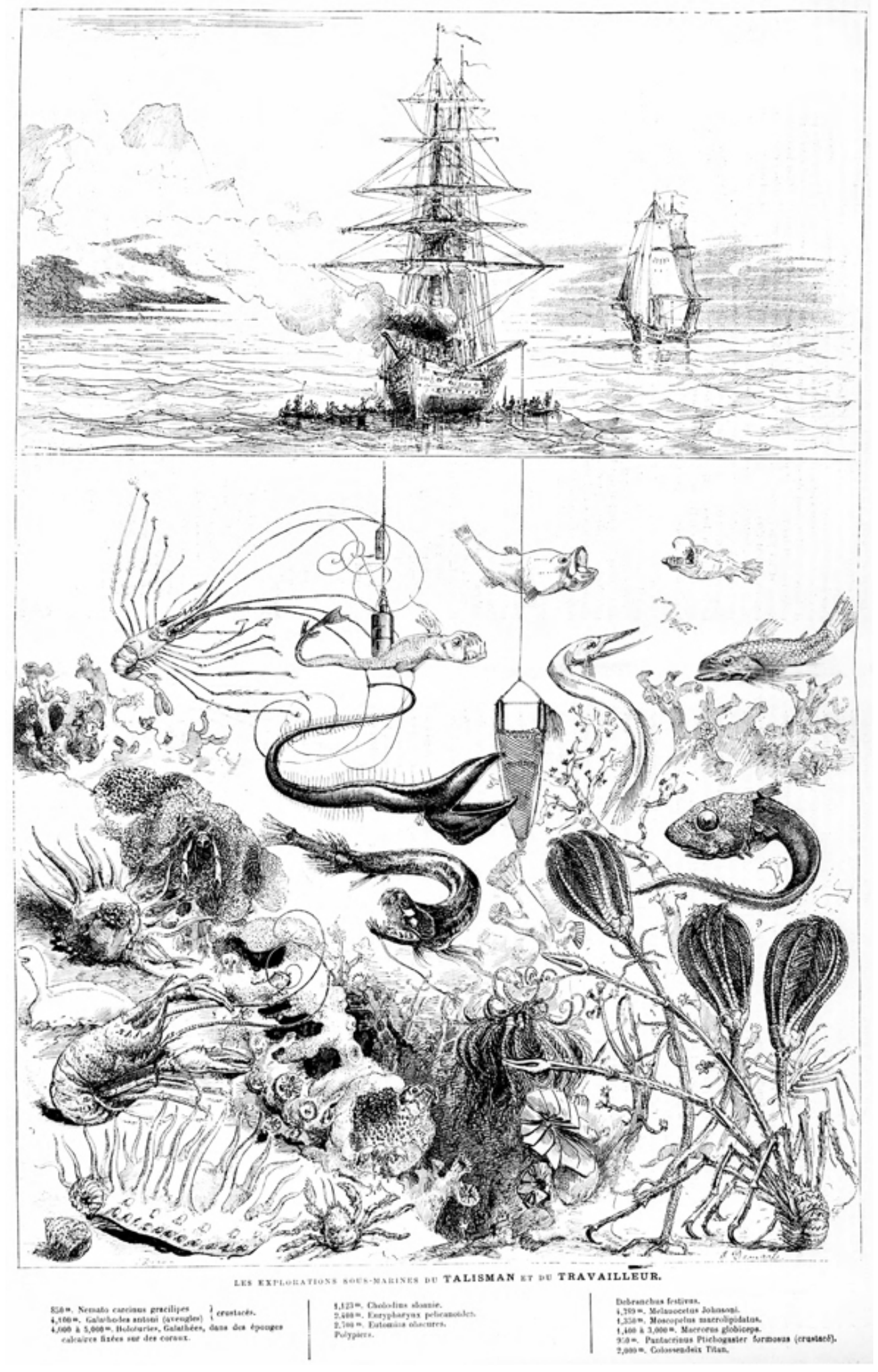

FIG 6. An illustration from the May 1885 issue of the magazine Journal des Voyages, a full year after the end of the exposition, showing the wonders of the deep revealed by the Travailleur and Talisman cruises. 


\section{Take-Home Lessons from 136 Years Ago}

While the press today is probably of less importance than social media, the strategies to use either effectively are perhaps fairly similar. Promotion first involved creating interest through a brief announcement. This was followed by piecemeal information feeds leading up to an official announcement. All along there was active solicitation of attention, in the form of inviting journalists for sneak previews. After the opening, the organizers, the Professors of the Natural History Museum created publicity themselves by authoring illustrated articles in magazines. Thus, they not only engaged media but also participated in it. Both before the Exposition and after, some Museum staff such as Pouchet and Perrier were regular contributors to the popular press. No doubt the fact that Milne Edwards was a charismatic figure with broad connections in society aided considerably. Today, scientists often shy away from media attention perhaps fearing the "Sagan Effect" (those given lots of media attention and participate in it probably don't do good work). However, in recent years it has become painfully obvious that science requires good spokespeople to express and defend science on many fronts. We often need to combat not only ignorance but also organized dis-information as well (e.g. Oreskes \& Conway 2010). Perhaps it is time that we take a cue from our naturalist predecessors from long ago and very actively participate in outreach?

Our naturalist predecessors appeared to have some institutional means of contacting the press. Today, we should be exploiting the fact that our institutions (our employers) generally have some sort of Press Office hungry for something to talk about. If you have something to tweet about, don't just tweet, contact your Press Office. They will quite possibly reply "Thanks but no thanks" but it costs very little to try. Journalist often scan institutional press releases for tidbits and ideas. Like our naturalist predecessors, consider also writing for the general public. A nice website that publishes short articles by academics but aimed a general audience is "The Conversation" with various national editions, and it is widely followed (https://theconversation.com). Traditional wide audience outlets such as Scientific American and Popular Science do consider article pitches. Again the reply could be "Thanks but no thanks" but it costs little to try.

\section{Sources Used}

Two web sources were used in gathering press reports, both from the Bibliothèque Nationale de France. The site Gallica was used to locate magazines by searching for works containing both of the terms "Travailleur" and "Talisman". The site RetroNews, an archive of French press, primarily newspapers, was used to locate newspaper articles containing both of the terms "Travailleur" and "Talisman" published between December 151883 and May 1884. For articles on the Cap Horn Expedition, searches were run for articles using the unusual name of the vessel, La Romanche, published between December 1882 and May 1884.

https://gallica.bnf.fr/accueil/en/content/accueil-en?mode=desktop https://www.retronews.fr 
Full references, with notes, of the press articles (all in French) are given in a supplementary file.

\section{References}

Anon. 1884a. The deep-sea dredging apparatus of the Talisman; The deep-sea fishes collected by the Talisman; The deep-sea crustacea dredged by the Talisman; The echinoderms dredged by the Talisman. Science, 3:448-455; 3:623-628; 3:713-716; 4:102-105.

Anon. 1884b. La mission Française de la Terre de Feu, Expostion du Cap Horn. La Nature, 12th year:273-275.

Bert, P.1884. L'expedition du "Talisman". Le Voltaire, 14 Feb. 1884, pg. 1

Carpine-Lancre, J. 2001. Oceanographic sovereigns: Prince Albert I of Monaco and King Carlos I of Portugal. Pp 56-68 in Understanding the Oceans. M. Deacon, T. Rice and C. Summerhayes, eds, UCL Press, London.

Dolan, J. R. 2020. The Origins of Oceanography in France: The Scientific Expeditions of Travailleur and Talisman (1880-1883). Oceanography, 33(2), https://doi.org/10.5670/oceanog.2020.202

Estival, B. 2003. Un Siécle de Navires Scientifiques Français, Paris, Editions Gerfaut, 160 pp.

Filhol, H. 1884. Explorations sous-marine, voyages du "Talisman". La Nature 12th year, 119-122; 134-138; 147-151; 161-164; 182-186; 198-202; 230-234; 278-282; 391-394.

Giffard, P. 1884. A 6000 métres sous le mers. Le Figaro, 23 Jan. 1884, pg. 5.

Milne Edwards, A. 1883. Rapport préliminaire sur l'expédition du Talisman dans l'Ocean Atlantique. Comptes Renudus des Séances de l'Acadamie des Sciences, 97: 1389-1395.

Nemo 1884. Mon cher directeur. Les Tablettes des Deux Charentes, 14 Feb. 1884, pg. 2.

Oreskes, N., Conway E.M. 2010. Merchants of Doubt. London, Bloomsbury Publishing, 368 pp.

Perrier, E. 1884. L'Exposition du "Talisman". Science et Nature, vol. 1, num. 15, 8 Mar. 1884, pg. 232-237.

Pouchet, G. 1883. M.A. Milne Edwards, la derniére campagne du Talisman dans l'Atlantique. Le Siécle, 30 Dec. 1883, pg. 1.

Second, H. 1884. Les Travailleurs de la mer. La France, 28 Jan. 1884, Pg. 2 
Verne, J. 1871. Vignt Milles Lieues sous Les Mers. Paris, J. Hetzel et Cie., 436 pp. 